Jurnal Ilmu-Ilmu Peternakan 25 (1): 55-60

ISSN: 0852-3581

E-ISSN: 9772443D76DD3

CFakultas Peternakan UB, http://jiip.ub.ac.id/

\title{
Pengaruh tepung tanaman meniran terhadap aktivitas antimikroba bakteri asam laktat dan Escherichia coli
}

\author{
Lestariningsih, Osfar Sjofjan dan Edhy Sudjarwo \\ Fakultas Peternakan Universitas Brawijaya \\ Jl. Veteran Malang - Jawa Timur \\ E-mail: taribrawijaya@yahoo.com
}

\begin{abstract}
The study was conducted to identify the effect of meniran plant powder (Phyllanthus niruri Linn.) on microorganism activity (Lactic Acid Bacteria (LAB) and Escherichia coli). The LAB extract was put in De Man, Rogosa and Sharpe (MRS) medium and the Escherichia coli extract was put in E-Coli Medium (EM). The pure culture LAB and Escherichia coli was used to identify the effect of meniran plant powder (Phyllanthus niruri Linn.) using diffusion method. The experiment consisted of 6 treatments $(\mathrm{P} 0=$ aquadest $100 \%, \mathrm{P} 1=$ antibiotic $100 \%, \mathrm{P} 2=$ meniran plant powder $0 \%$, $\mathrm{P} 3=$ meniran plant powder $50 \%, \mathrm{P} 4=$ meniran plant powder $75 \%$ and $\mathrm{P} 5=$ meniran plant powder 100\%). Variables in this research were inhibition of BAL and Escherichia coli. The study used a Nested Completely Randomized Design and if there were different effects among the treatments it would be then followed by a Duncan's Multiple Range test. The study showed that the use of meniran plant powder (Phyllanthus niruri Linn.) had a significant effect on inhibition of BAL and Escherichia coli $(\mathrm{P}<0.01)$.
\end{abstract}

Keywords: meniran plant, feed additive, Lactic acid bacteria and Escherichia coli

\section{PENDAHULUAN}

Tanaman obat memiliki kandungan bahan aktif yang dapat digunakan untuk pencegahan dan penyembuhan penyakit. Beberapa hasil penelitian secara in vitro melaporkan bahwa kualitas kandungan bahan aktif tanaman obat dapat berpotensi menghambat mikroorganisme (Kardinan dan Kusuma, 2004; Pourmorad et al., 2006; Sunarni et al., 2007; Rajeshwar et al., 2008; Venugopalan et al., 2010; Atanassova et al., 2011 dan Rahimi et al., 2011).

Selama ini penggunaan tanaman obat sudah banyak diaplikasikan dalam berbagai penelitian meskipun belum diketahui dosis yang tepat untuk menghambat aktivitas antimikroba BAL dan Escherichia coli (Gami dan Kothari, 2011). Tanaman meniran (Phyllanthus niruri Linn.) merupakan salah satu tanaman obat yang mengandung bahan aktif flavonoid sebesar $0,9982-1,85 \%$. Oleh karena itu, penelitian ini bertujuan mengidentifikasi pengaruh penggunaan tepung tanaman meniran terhadap aktivitas antibakteri BAL dan Escherichia coli.

\section{MATERI DAN METODE}

\section{Alat dan bahan \\ Peralatan yang digunakan adalah peralatan uji antimikroba bakteri yaitu}


cawan petri, tabung reaksi, gelas ukur, erlenmeyer, inkubator, timbangan ohaus, mikropipet $1 \mathrm{ml}$, autoklaf, waterbath dan magnetic stirrer. Bahan yang digunakan adalah aquades, antibiotik, tepung tanaman meniran, isolat BAL dengan media uji MRS-A dan isolat Escherichia coli dengan media uji EM-A.

\section{Prosedur penelitian}

Persiapan bahan dimulai dengan menyiapkan tepung fitobiotik dan diekstrak. Sterilisasi media dan peralatan menggunakan autoklaf pada suhu $121^{\circ} \mathrm{C}$ dalam waktu 15 menit serta uji aktivitas antibakteri menggunakan metode difusi agar.

\section{Penepungan tanaman meniran}

Tanaman meniran (akar, batang, daun dan biji) dicuci dan dioven selama 18 jam pada suhu $40{ }^{\circ} \mathrm{C}$. Setelah kering dihaluskan dengan grinder dan ditambah BHT 0,075\% per $1 \mathrm{~kg}$ tepung tanaman meniran (Rivai dkk, 2011).

\section{Persiapan sampel pengujian}

Tepung tanaman meniran
diencerkan menggunakan aquades
dengan perbandingan masing-masing
$(0 \%),(50 \%),(75 \%)$ dan $(100 \%) \mathrm{w} / \mathrm{v}$. Kemudian disaring menggunakan milipore dan hasil saringan digunakan sebagai sampel uji aktivitas hambatan bakteri.

\section{Pembuatan media MRS agar}

Pembuatan media MRS agar dilakukan dengan cara menimbang media sebanyak 46,5 g dan dilarutkan kedalam $750 \mathrm{ml}$ aquades. Media dan aquades dicampur supaya homogen dan dimasukkan kedalam Erlenmeyer 250 ml kemudian ditutup kapas dan dibungkus kertas kraf. Setelah itu bahan disterilisasi menggunakan autoklaf.

\section{Pembuatan media EM agar}

Pembuatan media EM agar dilakukan dengan cara menimbang media sebanyak $60 \mathrm{~g}$ dan dilarutkan kedalam $750 \mathrm{ml}$ aquades kemudian dicampur sampai homogen. Setelah itu dimasukkan kedalam Erlenmeyer, ditutup kapas dan dibungkus kertas kraf. Selanjutnya bahan disterilisasi menggunakan autoklaf.

\section{Uji aktivitas hambat mikroorganisme}

Pengujian aktivitas hambat mikroorganisme menggunakan metode difusi agar yang dimulai dengan mempersiapkan alat dan bahan, membuat media MRS dan EM. Selanjutnya alat dan bahan disterilisasi menggunakan autoklaf. Uji aktivitas hambat mikroorganisme dimulai dengan memasukkan media agar kedalam cawan petri sebanyak $\pm 22 \mathrm{ml}$ dan dimasukkan juga kultur bakteri sebanyak $1 \mathrm{ml}$ kedalam cawan petri yang berisi media agar tersebut. Setelah itu dihomogenkan dengan cara membentuk angka delapan.

Selanjutnya didiamkan selama 3-5 menit hingga media agar padat dan dibuat sumuran di tengah cawan petri yang berisi media agar menggumpal dengan diameter $0,70 \mathrm{~cm}$. Sumuran tersebut ditetesi fitobiotik sebanyak 30 $\mu l$ dan selanjutnya cawan petri tersebut diinkubasi selama 24 jam pada suhu 37 ${ }^{\circ} \mathrm{C}$. Selanjutnya diameter zona hambatan diukur menggunakan penggaris dengan satuan $\mathrm{cm}$.

\section{Analisis data}

Semua data yang diperoleh dari penelitian ditabulasi menggunakan Rancangan Acak Lengkap (RAL) dan apabila terdapat perbedaan pengaruh yang nyata atau sangat nyata dilanjutkan dengan uji jarak berganda Duncan's (Yitnosumarto, 1993). 


\section{HASIL DAN PEMBAHASAN}

\section{Pengaruh penggunaan tepung tanaman meniran terhadap aktivitas antibakteri (bakteri asam laktat dan Escherichia coli)}

Tepung meniran mempunyai bahan aktif flavonoid yang berpotensi sebagai antibakteri. Antibakteri adalah suatu senyawa kimia khas yang dihasilkan oleh organisme hidup dalam konsentrasi rendah dan mampu menghambat proses penting dalam suatu mikroorganisme (Siswandono dan Soekardjo, 1995 dalam Paramita, 2010). Berdasarkan aplikasi percobaan laboratorium, penggunaan meniran dapat digunakan sebagai antibakteri (Kardinan et al., 2004; Pourmorad et al., 2006; Sunarni dkk., 2007; Rajeshwar et al., 2008; Venugopalan et al., 2010; Atanassova et al., 2011 dan Rahimi et al., 2011). Selain itu, Gami dan Kothari (2011) melaporkan bahwa kandungan flavonoid sebesar 0,9982 $1,85 \%$ menentukan kualitas tanaman meniran.
Potensi antibakteri tepung tanaman meniran dalam penelitian ini diukur menggunakan pengukuran aktivitas antibakteri metode difusi sumur agar. Hasil penghambatan dalam metode tersebut dapat diketahui dengan mengukur diameter zona hambat. Garis tengah zona hambatan jernih yang mengelilingi obat dianggap sebagai ukuran kekuatan hambatan terhadap bakteri yang dihasilkan (Rahayu dkk., 2009). Parameter bakteri yang digunakan dalam penelitian ini adalah BAL (bakteri gram positif) dan Escherichia coli (bakteri gram negatif). Hal tersebut bertujuan untuk mengetahui perbandingan besarnya hambatan bakteri gram prositif dan gram negatif.

Data hasil penelitian penggunaan tepung tanaman meniran sebagai aditif pakan terhadap diameter zona hambat bakteri asam laktat dan Escherichia coli ditampilkan pada Tabel 1.

Tabel 1. Diameter zona hambat bakteri asam laktat dan Escherichia coli

\begin{tabular}{|c|c|c|}
\hline \multirow{2}{*}{ Perlakuan } & \multicolumn{2}{|c|}{ Diameter zona hambat (mm) } \\
\hline & Bakteri asam laktat & Escherichia coli \\
\hline $\mathrm{P}$ & $0,00 \pm 0,00^{\mathrm{a}}$ & $0,00 \pm 0,00^{\mathrm{a}}$ \\
\hline $\mathrm{P}$ & $27,75 \pm 1,50^{\mathrm{e}}$ & $33,75 \pm 1,71^{\mathrm{e}}$ \\
\hline $\mathrm{P}$ & $0,00 \pm 0,00^{\mathrm{a}}$ & $0,00 \pm 0,00^{\mathrm{a}}$ \\
\hline $\mathrm{P}$ & $10,25 \pm 2,50^{b}$ & $18,25 \pm 1,71^{\mathrm{b}}$ \\
\hline $\mathrm{P}$ & $14,25 \pm 4,43^{c}$ & $23,00 \pm 2,45^{\mathrm{d}}$ \\
\hline $\mathrm{P}$ & $15,75 \pm 4,35^{\mathrm{d}}$ & $19,25 \pm 0,96^{\mathrm{c}}$ \\
\hline
\end{tabular}

Keterangan : Superskrip ${ }^{(a-d)}$ dalam kolom yang sama menunjukkan perbedaan yang sangat berbeda nyata $(\mathrm{P}<0,01)$

Tabel 1 menunjukkan bahwa tepung tanaman meniran mampu menghambat BAL dan Escherichia coli. Hal ini menunjukkan bahwa tepung tanaman meniran mempunyai potensi sebagai antibakteri yang berspektrum luas. Siswandono dan Soekardjo (1995) dalam Paramita (2010) menyatakan bahwa berdasarkan perbedaan sensitivitas terhadap bakteri, antibakteri dibedakan menjadi dua kelompok besar yaitu antibakteri berspektrum luas (antibakteri tersebut menghambat sejumlah bakteri gram positif dan gram negatif) dan kelompok kedua yaitu anti bakteri berspektrum sempit (antibakteri 
tersebut hanya mampu menghambat bakteri tertentu saja). Namun demikian, flavonoid dalam penghambatannya bersifat bakteriostatik (Rattanachaikunsopon and Phumkhachorn, 2010; Manimozhi et al., 2012). Bakteri yang telah dihambat oleh flavonoid masih dapat tumbuh pada media lain yang tidak terdapat flavonoid (penghambatan sementara). Selain itu, flavonoid dapat menembus dinding sel bakteri (Cushnie and Lamb, 2005). Glikosilase pada flavonoid ditunjukkan aktif berperan dalam aktivitas antibakteri flavonoid.

Tabel 1 juga menunjukkan semakin tinggi pemberian konsentrasi antimikroba yang terdapat dalam tepung tanaman meniran maka semakin tinggi pula diameter zona hambat yang dihasilkan terhadap BAL dan Escherichia coli. Hal tersebut sesuai dengan pendapat Akroum et al. (2009) yang melaporkan bahwa semakin tinggi penggunaan konsentrasi flavonoid maka semakin tinggi pula kemampuan antibakterinya. Meskipun demikian, hasil tersebut masih jauh lebih rendah dibandingkan dengan zona hambat yang dihasilkan oleh antibiotik komersial. Hal tersebut sesuai dengan pendapat Gunawan dkk. (2008) dan Rudiyanto (2006) yang menyatakan bahwa tanaman obat yang mengandung flavonoid mempunyai potensi untuk menghambat bakteri gram positif dan bakteri gram negatif seperti bakteri Escherichia coli dan Staphylococcus aureus. Hal ini membuktikan bahwa ekstrak tanaman meniran mempunyai efek antibakteri paling tinggi terhadap bakteri Staphylococcus aureus, Bacillus subtilis, Escherichia colli, dan Pseudomonas aeruginosa (Bylka et al., 2004; Cushnie and Lamb, 2005 serta Joseph and Raj, 2011).

Selain itu, Tabel 1 juga menunjukkan pada perlakuan kontrol yang terdiri dari aquades dan pemberian tepung tanaman meniran 0\% tidak terdapat zona hambatan yang berarti tidak adanya penghambatan oleh antimikroba.

\section{KESIMPULAN}

Penelitian ini menyimpulkan bahwa penggunaan tepung tanaman meniran memiliki efek yang signifikan terhadap aktivitas antibakteri BAL dan Escherichia coli. Konsentrasi penggunaan tepung tanaman meniran terbaik terhadap aktivitas antibakteri terjadi pada level $100 \%$.

\section{DAFTAR PUSTAKA}

Akroum, S., D. Bendjeddou, D. Satta and K. Lalaoul. 2009. Antibacterial activity and acute toxicity effect of flavonoids extracted from mentha longifolia. American-Eurasian Journal of Scientific Research. Vol. 4 (2): 93-96.

Atanassova, M., S. Georgieva and K. Ivancheva. 2011. Total phenolic and total flavonoid contents, antioxidant capacity and biological contaminants in medicinal herbs. Journal of University of Chemical Technology and Metallurgy. Vol. 46 (1): 81-88.

Bylka, W, I. Matlawska and N. A. Pilewski. 2004. Natural flavonoids as antimicrobial agents. JANA. Vol. 7 (2).

Cushnie, T. P. T. and A. J. Lamb. 2005. Antimicrobial activity of flavonoids. International Journal of Antimicrobial Agents. Vol. 26: 343-356.

Gami, B and I. L. Kothari. 2011. Antioxidant and antimicrobial activity of in vivo and in vitro grown plants of Phillanthus 
niruri. International Journal Pharma and Bio Science. Vol. 2.

Gunawan, I. W. G., I. G. A. G. Bawa dan N. L. Sutrisnayanti. 2008. Isolasi dan identifikasi senyawa terpenoid yang aktif antibakteri pada herba meniran. Jurnal Kimia. Vol. 2 (1): 31 39.

Joseph, B and S. J. Raj. 2011. An overview: pharmacognostic properties of Phyllanthus amarus Linn. Intenational Journalof Pharmacology. Vol. 7 (1): 40-45.

Kardinan, A., dan Kusuma F. R. 2004. Meniran penambah daya tahan tubuh alami. Agromedia Pustaka. Jakarta.

Manimozhi, $\quad$ D. $\quad$ M., S. Sankaranarayanan and G. Sampathkumar. 2012. Evaluating the antibacterial activity of flavonoid extracted from Ficus benghalensis. International Journal of Pharmaceutical and Biological Research. Vol. 3 (1).

Pourmorad, F., S. J. Hosseinimehr and N. Shahabimajd. 2006. Antioxidant activity, phenol and flavonoid contents of some selected iranian medicinal plants. African Journal of Biotechnology. Vol. 5 (11): 1142-1145.

Rahayu, M. P., W. Kartinah, dan P. Aditya. 2009. Uji aktifitas antibakteri ekstrak soxhletasi dan maserasi buah makasar (Brucea javanica (l) Merr.) terhadap bakteri Shigella dysentriae ATCC 9361 secara in vitro. Biomedika. Vol. 2 (1): 1979-35X.

Rahimi, S., Z. T. Zadeh, M. A. K. Torshizi, R. Omigbaigi, and $\mathrm{H}$. Rokni. 2011. Effect of the three herbal extracts on growth performance, imun system, blood factors and intestinal selected bacterial population on broiler chickens. Journal Agriculture Science Technology. Vol. 13: 527-537.

Rajeshwar, Y., R. Ahmad, A. S. Sunder, J. Devilal, M. Gupta and U. K. Mazumder. 2008. In vitro peroxidation inhibitory and antimicrobial activity of Phyllanthus niruri (Euphorbiaceae) extract. Iranian Journal of Pharmacology and Therapeutics. HIm. 67-70.

Rattanachaikunsopon, P. and P. Phumkhachorn. 2010. Contents and antibacteria activity of flavonoids extracted froleaves of psidium guajava. Journal of Medicinal Plants Research. Vol. 4 (5): 393-396.

Rivai, H., H. Nurdin, H. Suryani dan A. Bachtiar. 2011. Pengaruh cara pengeringan terhadap mutu meniran (Phyllanthus niruri L.). Majalah Farmasi Indonesia. Vol. 22 (1): 73-76.

Rudiyanto, W. 2006. Efek ekstrak etanol herba meniran (Phyllantus niruri L.) terhadap organ hati tikus setelah pemberian karbon tetraklorida (CCL4). Tesis. Universitas Gadjah Mada. Yogyakarta.

Sunarni, T., S. Pramono dan R. Asmah. 2007. Flavonoid antioksidan penangkap radikal bebas dari daun kepel. Majalah Farmasi Indonesia, Vol. 18 (3): 111-116.

Siswandono dan B. Soekardjo. 1995. Kimia medical. Airlangga University Press. Surabaya. Dalam Paramita, V. 2010. Mikroenkapsulasi dalam industri pangan. Majalah Inovasi. IPTEK Inovasi. 16 (XXII). 
Venugopalan, V., M. S. Dinesh and K. S. Geetha. 2010. Enhancement of antimicrobial potential of Phyllanthus niruri by fermentation. Journal of Herbal
Medicine and Toxicology. Vol. 4 (2): 176-175.

Yitnosumarto, S. 1993. Percobaan perancangan analisa dan interpretasinya. Gramedia Pustaka Utama. Jakarta. 